\title{
Gastrointestinal Stromal Tumors (GISTs). Single Center Experience Observed in a Small Series of Cases
}

\author{
Tumores del Estroma Gastrointestinal (GISTs). Experiencia \\ de un Centro Único en una Serie de Casos
}

Carlos Manterola ${ }^{*, * *, * * * ;}$; Tamara Otzen ${ }^{* * *, * * * * *, * * * * * * *} \&$ MInCir Group ${ }^{* * *}$

MANTEROLA, C. \& OTZEN, T. \& MINCIR GROUP. Gastrointestinal stromal tumors (GISTs). Single center experience observed in a small series of cases. Int. J. Morphol., 34(2):478-483, 2016.

SUMMARY: Gastrointestinal stromal tumors (GISTs) are the most common mesenchymal neoplasms developing in the stomach. Usually detected incidentally, they can be single or multiple. The aim of this study is to report the results of surgery in the treatment of GISTs in terms of postoperative morbidity (POM) and recurrence. Case series. Patients surgically treated by GISTs at the Clínica Mayor of Temuco, Chile, between 2008 and 2015 were included. The preoperative study consisted in general diagnostic tests, endoscopy and abdominal CT-Scan. The outcome variable was POM, measured at 30 days postoperatively. Other variables of interest were: surgical time, hospital stay, mortality and recurrence. Minimum follow-up time was 12 months. Descriptive statistics were used. Four patients with GISTs were operated in the study period. Median age was 67 years, and $50 \%$ of the patients were female. The median time of symptoms was 6 months. Excision of the lesion was performed in all cases with a median surgical time of 129 min. POM was $25 \%$ (one case developed a seroma of the surgical wound), grade I of Clavien \& Dindo proposal. Hospital stay was 4 day in all cases and no operative mortality was reported. With a median follow-up of 24 months there was not evidenced of recurrence. Although the results were positive, it is worth mentioning that this was a very small number of cases, therefore, they should be considered with caution.

KEY WORDS: Gastrointestinal stromal tumors; Gastrointestinal stromal tumors/surgery; Gastrointestinal stromal tumors/therapy; Neoadjuvant therapy; GISTs.

\section{INTRODUCTION}

Although gastrointestinal stromal tumors (GISTs) are a uncommon entity, prevalence in general population detected by abdominal ultrasonography is between $0.5 \%$ and $5.0 \%$ (Blanke \& Corless, 2005; Blay et al., 2005; Heinrich \& Corless, 2005). On the other hand, in adult autopsies prevalence between $1.0 \%$ and $5.0 \%$ has been reported. It is a disease more frequent in women, and although the vast majority are asymptomatic, can become symptomatic in patients between 40 and 50 years of age.

Until a short time ago, there were few successful therapeutic options for patients with GISTs. The majority of patients were submitted to surgery for curative resection in early-stage disease. On the other hand, the evidence does not support the treatment of advanced tumors with systemic chemotherapy. However, molecularly targeted agents, such as Imatinib, have been demonstrated to be highly effective at inducing objective responses in GIST patients improving overall survival, used either pre or postoperative (Blanke \& Corless; Tielen et al., 2013).

Since the first reports in the decade of the $80 \mathrm{~s}$ (Hjermstad et al., 1987), enough evidence was reported supporting the role of surgery in GISTs. In fact, there are 5 related systematic reviews comparing laparoscopic vs. open surgery for GISTs of the stomach. The first one comprises 17 studies involving 776 participants, concludes that laparoscopic was associated with less blood loss, earlier return of bowel function and shorter length of hospital stay (Liang et al., 2013). The second one composed of 11 nonrandomized studies and 765 patients conclude that laparoscopic results of short-term postoperative outcomes

* Department of Surgery and Traumatology, Universidad de La Frontera, Temuco, Chile.

** CEMyQ, Universidad de La Frontera, Temuco, Chile.

*** Center for Biomedical Research, Universidad Autónoma, Temuco, Chile.

***** Ph.D. Program in Medical Sciencies, Universidad de La Frontera, Temuco, Chile.

****** Universidad de Tarapacá, Arica, Chile 
are superior without compromising oncological safety and long-term oncological outcomes (Koh et al., 2013). The third one, comprising 12 articles and 644 patients concludes that laparoscopic surgery was associated with a reduction in intraoperative blood loss, earlier resumption of oral intake and shorter duration of hospital stay over the short-term, and with a significantly lower rate of overall recurrence, metastatic and local recurrence in the long-term compared to open surgery (Ohtani et al., 2013). The fourth one, of 22 studies including 1,166 patients concludes that laparoscopic surgery for gastric GISTs is acceptable for selective patients (Chen et al., 2014). Lastly, one of 19 studies and 1,060 cases concludes that laparoscopic approach had better results in terms of blood loss, postoperative morbidity (POM) and recovery (Chen et al., 2015).

The report of this study, was made according to the checklist for descriptive observational studies published by our research group (Manterola \& Astudillo, 2013).

The aim of this study is to report the results of surgery in the treatment of GISTs in terms of POM and recurrence.

\section{MATERIAL AND METHOD}

Design: Retrospective case series.

Setting: The study was conducted at the Clínica Mayor de Temuco, Chile, between January 2008 and January 2015 (7 years).

Participants: Subjects with single or multiple GIST. The preoperative study consisted of general exams, endoscopy (Fig. 1) and abdominal CT-Scan. All patients that underwent surgery for GISts in the study period by the first author were included.

Sampling: Non-probabilistic sampling of consecutive cases.

Surgical technique: Surgery was performed with the patients under general anesthesia. The type of resection varies depending on the organ involved. Thus, partial gastrectomy and partial resection of the small bowel were performed (Fig. 2). Finally, specimens were sent to the Pathology Department (Fig. 3).

Variables: The outcome variable was POM, measured at 30 days postoperatively applying the Clavien proposal (Clavien et al., 2009). Other variables of interest were: surgical time, hospital stay, mortality and recurrence.

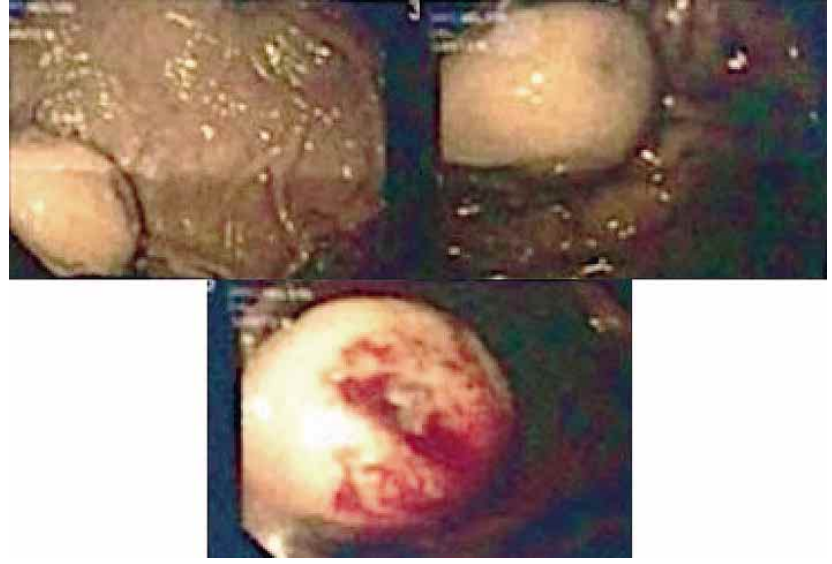

Fig. 1. Endoscopic view of a gastric GIST.

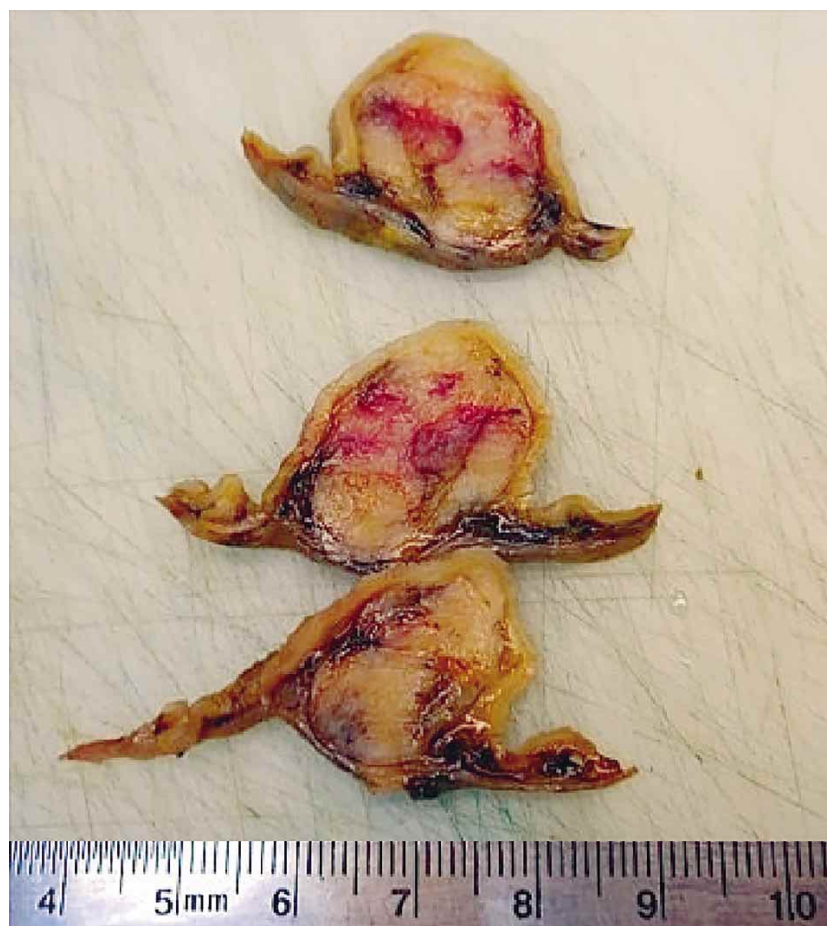

Fig. 2. Surgical specimen of a gastric GISTprepared in several longitudinal sections for histological study.

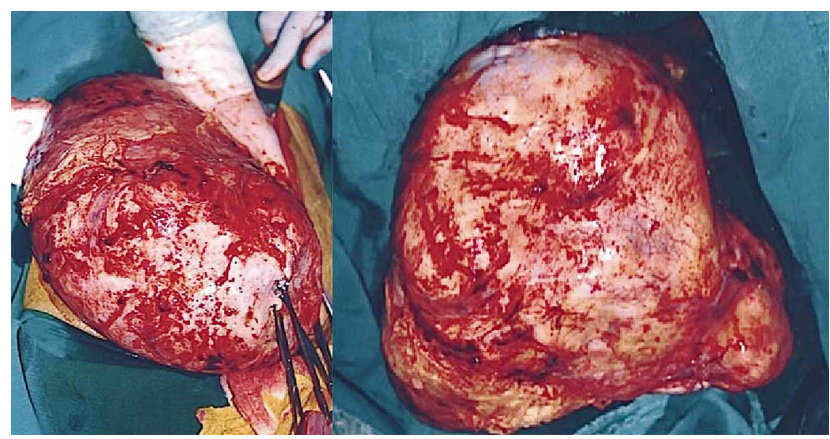

Fig. 3. Macroscopic view of an intestinal GIST once exteriorized and completely resected, with its capsule intact. 
Follow-up protocol: Patients were checked at the first week and then at months 1, 3, 6, 12, 24 and 36 after surgery with endoscopy and abdominal CT-Scan intended to verify clinical evolution and discard recurrence. All patients have been followed and controlled at least for 12 months.

Statistics: Descriptive statistics (calculation of percentages, median, minimum and maximum values) were used.

Ethics: All patients signed their informed consent forms and its identity was reserved by using codes.

\section{RESULTS}

In the study period 4 patients with GISTs were treated in this way. The median age was 67 years (61 to 75 ) and $50 \%$ were feminine. Median of mass body index was 28 (22.9 to 39.0$)$.

The median time of symptoms was 6 months (6 to 12). All patients had comorbidities (arterial hypertension, diabetes mellitus type II, abdominal hernia and cholelitiasis).
Three of the patients had gastric location (anterior face of the great curve, anterior face of minor curve and in the backside of the great curve). The other patient had a small bowel location (approximately $200 \mathrm{~cm}$ from the duodenojejunal union).

The median surgical time was $129 \min (100$ to 180$)$. The following surgical procedures were performed: Partial gastrectomies (3 cases) and intestinal resection (1 case).

POM was $25 \%$ (one case developed a seroma of the surgical wound), grade I of Clavien. Hospital stay was 4 day in all cases, and no operative mortality occurred.

With a median follow-up time of 24 months (minimum of 12 month and a maximum of 60 months), there was no evidence of recurrence.

The histopathological study confirmed GISTs in all specimens. In one patient a simultaneous lesion was surveyed and resected and a Gastrointestinal Autonomic Nerve Tumor (GANT) of gastric location was reported.

Table I. Reported experience with surgery for gists from 2000 to 2015 (n >50).

\begin{tabular}{|c|c|c|c|c|c|c|c|}
\hline $\begin{array}{l}\text { Author } \\
\text { (year) }\end{array}$ & $n$ cases & $\begin{array}{c}\text { Gastric } \\
\text { Location (\%) }\end{array}$ & $\begin{array}{l}\text { Diameter } \\
(\mathbf{c m})\end{array}$ & $\begin{array}{c}\text { Resected } \\
(\%)\end{array}$ & $\begin{array}{c}\text { Follow-up } \\
\text { (mean, months) }\end{array}$ & $\begin{array}{c}\text { Recurrence } \\
(\%)\end{array}$ & $\begin{array}{c}\text { OST } \\
(\%, 5 \text { years })\end{array}$ \\
\hline DeMatteo et al. (2000) & 200 & 39.0 & 2.9 & 86.0 & 24.0 & 40.0 & $\mathrm{NR}$ \\
\hline Pierie et al. (2001) & 69 & 61.0 & 7.9 & 59.0 & 38.0 & 41.0 & NR \\
\hline Wong et al. (2003) & 108 & NR & NR & 100 & NR & NR & 42.0 \\
\hline Lin et al. (2003) & 81 & 54.0 & 7.5 & 77.0 & NR & 39.0 & NR \\
\hline Kim et al. (2004) & 86 & NR & 6.0 & 85.0 & 35.7 & 34.0 & NR \\
\hline Martin et al. (2005) & 162 & 57.0 & 6.0 & 100 & 42.0 & 26.0 & 68.0 \\
\hline Wu etal. (2006) & 100 & 100 & NR & 85.0 & 44.0 & NR & 52.0 \\
\hline Bümming et al. (2006) & 259 & 55.2 & NR & NR & NR & 17.0 & NR \\
\hline Bucher et al. (2006) & 80 & 58.0 & 5.0 & 90.0 & 42.0 & NR & NR \\
\hline Rutowsky et al. (2007) & 335 & 45.7 & 2.9 & 100 & 31.0 & 45.0 & 37.8 \\
\hline An et al. (2007) & 111 & 100 & NR & NR & 23.0 & 35.0 & NR \\
\hline Richter et al. (2008) & 54 & 50.0 & 6.1 & 100 & NR & 21.0 & NR \\
\hline Hassan et al. (2008) & 191 & 54.0 & NR & 95.0 & 63.0 & NR & NR \\
\hline Ahmed et al. (2008) & 185 & 52.0 & 6.7 & 83.0 & 81.6 & 11.0 & NR \\
\hline Silberhumer et al. (2009) & 63 & 100 & 5.3 & 100 & 30 & 7.0 & NR \\
\hline Cao et al. (2010) & 181 & 59.1 & 7.0 & 97.2 & NR & NR & 78.5 \\
\hline Manrique, 2012 & 103 & 56.3 & 9.8 & 87.4 & NR & NR & 31.1 \\
\hline Schwameis, 2013 & 159 & NR & NR & 91.4 & 97.2 & NR & 54.0 \\
\hline Tielen etal. (2013) & 57 & NR & 12.2 & 84.0 & NR & 14.0 & 77.0 \\
\hline Bellorin et al. (2014) & 486 & 100 & NR & 100 & NR & NR & NR \\
\hline Sorour et al. (2014) & 92 & 53.0 & NR & 97.8 & 60.0 & 12.2 & 81.4 \\
\hline De Vogelaere et al. (2014) & 64 & 94.0 & 7.9 & 100 & NR & 6.3 & 94.0 \\
\hline Zovak et al. (2014) & 54 & NR & NR & 81.5 & 46.8 & NR & NR \\
\hline
\end{tabular}

$\mathrm{NR}=$ Not reported; OST= Overall survival time; Resected= Percentage of resected patients over the total of the series. 


\section{DISCUSSION}

GISTs are the most frequent mesenchymal neoplasm developing in the stomach. Their natural history, particularly those of less than $2 \mathrm{~cm}$ in diameter, is still unknown. Habitually, GISTs have been treated surgically, because there was no proven role of other therapy modalities such as chemotherapy or radiation. However, in 1998 it was discovered that the vast majority of GISTs have oncogenic gain-of-function mutations of the KIT receptor tyrosine kinase. That is how follow-up studies have confirmed that KIT is a useful diagnostic marker and an excellent therapeutic target. Consequently, in the past years, Imatinib (inhibitor of KIT kinase activity) has been used as therapy for patients with advanced, recurrent and metastatic GIST (Heinrich \& Corless; Schindler et al., 2005; Fernández \& Parrilla; 2009; Parikh \& Gupta, 2013; Chang et al., 2015), as well as adjuvant neo-adjuvant protocols (Blay et al.; Reichardt et al., 2012; Parikh \& Gupta; Chang et al.).

On the other hand, there is a lot of evidence that support the role of surgery in GISTs treatment. In fact, evidence based on an update provided by the NCCN Task Force report, supports that surgery remains the treatment of choice in patients with primary localized and non-metastatic GISTs (Demetri et al., 2010).

GIST tumors have a number of characteristics that facilitate their surgery. Despite being able to develop liver and peritoneal metastases, very rarely give lymphatic metastases that make it unnecessary an associated lymphadenectomy in the surgical approach. They develop expansively but not infiltrative which permit to realize limited resections (Demetri et al.; Blay et al.; Fernández et al., 2010; Kasetsermwiriya et al., 2015). If resection of localized primary GIST is complete, the prognosis is appropriate, with survival rates of $40-55 \%$ at 5 years (DeMatteo et al., 2000). In this aspect is fundamental the exeresis of the complete lesion including the pseudocapsule to avoid leaving any tumoral foci. In fact, his rupture would amount to a $\mathrm{R} 2$ resection consequently no simple enucleation is recommended (Pierie et al., 2001; Kasetsermwiriya et al.).

The great majority of published series are smaller than 50 cases, therefore, the series of Ahmed, An, Hassan, Martin and Wong with casuisticals higher to 100 cases (Cao et al., 2010; Ahmed et al., 2008; An et al., 2007; Hassan et al., 2008; Manrique et al., 2012; Martín et al., 2005; Wong et al., 2003) are noteworthy, and those from DeMatteo et al., Bümming et al. (2006) and Rutowsky et al. (2007) with casuisticals over than 200 treated patients (Bellorin et al., 2014; Bümming et al.; DeMatteo et al.; Rutkowski et al.).
In Table I the results of diverse published series are exposed. The analysis of each one of these studies, allow verification that with a few exceptions there are no large number series, the majority are retrospective, operated by open and laparoscopic surgery, with and without the use of Imatinib, and include primary tumors, recurrences and even metastases. This great heterogeneity makes it difficult to analyze the data.

In conclusion, it should be mentioned that although the results are positive and worthwhile mentioning, the study includes a very small number of cases, therefore they should be considered with caution.

MANTEROLA, C. \& OTZEN, T. \& MINCIR GROUP. Tumores del estroma gastrointestinal (GISTs). Experiencia de un centro único en una serie de casos. Int. J. Morphol., 34(2):478-483, 2016.

RESUMEN: Los tumores del estroma gastrointestinal (GISTs), son las neoplasias del mesénquima más comunes del estómago. Su detección es usualmente incidental; y pueden ser únicas o múltiples. El objetivo de este estudio, es reportar los resultados de la cirugía en el tratamiento de los GISTs en términos de morbilidad postoperatoria (MPO) y recurrencia. Serie de casos retrospectiva. Se incluyeron los pacientes intervenidos quirúrgicamente por GISTs en la Clínica Mayor de Temuco, Chile, entre los años 2008 y 2015. El estudio preoperatorio consistió en pruebas diagnósticas generales, endoscopia y tomografía computarizada abdominal. La variable resultado fue MPO medida a los 30 días del postoperatorio. Otras variables de interés fueron: tiempo quirúrgico y de hospitalización, mortalidad y recurrencia. El tiempo de seguimiento mínimo considerado fue 12 meses. Se utilizó estadística descriptiva. En el período en estudio, se operaron 4 pacientes con GISTs. La mediana de edad fue 67 años y el $50 \%$ de los casos era de sexo femenino. La mediana del tiempo de síntomas fue 6 meses. La exéresis de las lesiones se realizó en todos los casos, con una mediana de tiempo quirúrgico de 129 min. La MPO fue $25 \%$ (un paciente desarrolló un seroma de la herida quirúrgica), grado I de Clavien \& Dindo. La estadía hospitalaria fue de 4 días en todos los casos. No hubo mortalidad; y con una mediana de seguimiento de 24 meses, no se ha evidenciado recurrencia. Si bien los resultados son buenos en todas las variables observadas, es fundamental señalar que se trata de un pequeño número de casos; por ende, deben considerarse con precaución.

PALABRAS CLAVE: Tumores del estroma gastrointestinal; neoplasias del estómago; GIST.

\section{REFERENCES}

Ahmed, I.; Welch, N. T. \& Parsons, S. L. Gastrointestinal stromal tumours (GIST) - 17 years experience from Mid Trent Region (United Kingdom). Eur. J. Surg. Oncol., 34(4):445-9, 2008. 
An, J. Y.; Choi, M. G.; Noh, J. H.; Sohn, T. S.; Kang, W. K.; Park, C. K. \& Kim, S. Gastric GIST: a single institutional retrospective experience with surgical treatment for primary disease. Eur. J. Surg. Oncol., 33(8):1030-5, 2007.

Bellorin, O.; Kundel, A.; Ni, M. \& Litong, D. Surgical management of gastrointestinal stromal tumors of the stomach. J. S. L. S., 18(1):46-9, 2014.

Blanke, C. D. \& Corless, C. L. State-of-the art therapy for gastrointestinal stromal tumors. Cancer Invest., 23(3):274-80, 2005.

Blay, J. Y.; Bonvalot, S.; Casali, P.; Choi, H.; Debiec-Richter, M.; Dei Tos, A. P.; Emile, J. F.; Gronchi, A.; Hogendoorn, P. C.; Joensuu, H.; Le Cesne, A.; McClure, J.; Maurel, J.; Nupponen, N.; Ray-Coquard, I.; Reichardt, P.; Sciot, R.; Stroobants, S.; van Glabbeke, M.; van Oosterom, A.; Demetri, G. D. \& GIST consensus meeting panelists. Consensus meeting for the management of gastrointestinal stromal tumors. Report of the GIST Consensus Conference of 20-21 March 2004, under the auspices of ESMO. Ann. Oncol., 16(4):566-78, 2005.

Bucher, P.; Egger, J. F.; Gervaz, P.; Ris, F.; Weintraub, D.; Villiger, P.; Buhler, L. H. \& Morel, P. An audit of surgical management of gastrointestinal stromal tumours (GIST). Eur. J. Surg. Oncol., 32(3):310-4, 2006.

Bümming, P.; Ahlman, H.; Andersson, J.; Meis-Kindblom, J. M.; Kindblom, L. G. \& Nilsson, B. Population-based study of the diagnosis and treatment of gastrointestinal stromal tumours. Br. J. Surg., 93(7):836-43, 2006.

Cao, H.; Zhang, Y.; Wang, M.; Shen, D. P.; Sheng, Z. Y.; Ni, X. Z.; Wu, Z. Y.; Liu, Q.; Shen, Y. Y. \& Song, Y. Y. Prognostic analysis of patients with gastrointestinal stromal tumors: a single unit experience with surgical treatment of primary disease. Chin. Med. J. (Engl.), 123(2):131-6, 2010.

Chang, S. C.; Liao, C. H.; Wang, S. Y.; Tsai, C. Y.; Chiang, K. C.; Cheng, C. T.; Yeh, T. S.; Chen, Y. Y.; Ma, M. C.; Liu, C. T. \& Yeh, C. N. Feasibility and timing of cytoreduction surgery in advanced (metastatic or recurrent) gastrointestinal stromal tumors during the era of imatinib. Medicine (Baltimore), 94(24):e1014, 2015.

Chen, K.; Zhou, Y. C.; Mou, Y. P.; Xu, X. W.; Jin, W. W. \& Ajoodhea, H. Systematic review and meta-analysis of safety and efficacy of laparoscopic resection for gastrointestinal stromal tumors of the stomach. Surg. Endosc., 29(2):355-67, 2015.

Chen, Q. L.; Pan, Y.; Cai, J. Q.; Wu, D.; Chen, K. \& Mou, Y. P. Laparoscopic versus open resection for gastric gastrointestinal stromal tumors: an updated systematic review and metaanalysis. World J. Surg. Oncol., 12:206, 2014.

Clavien, P. A.; Barkun, J.; de Oliveira, M. L.; Vauthey, J. N.; Dindo, D.; Schulick, R. D.; de Santibañes, E.; Pekolj, J.; Slankamenac, K.; Bassi, C.; Graf, R.; Vonlanthen, R.; Padbury, R.; Cameron,
J. L. \& Makuuchi, M. The Clavien-Dindo classification of surgical complications: five-year experience. Ann. Surg., 250(2):187-96, 2009.

DeMatteo, R. P.; Lewis, J. J.; Leung, D.; Mudan, S. S.; Woodruff, J. M. \& Brennan, M. F. Two hundred gastrointestinal stromal tumors: recurrence patterns and prognostic factors for survival. Ann. Surg., 231(1):51-8, 2000.

Demetri, G. D.; von Mehren, M.; Antonescu, C. R.; DeMatteo, R. P.; Ganjoo, K. N.; Maki, R. G.; Pisters, P. W.; Raut, C. P.; Riedel, R. F.; Schuetze, S.; Sundar, H. M.; Trent, J. C. \& Wayne, J. D. NCCN Task Force report: update on the management of patients with gastrointestinal stromal tumors. J. Natl. Compr. Canc. Netw., 8 (Suppl. 2):S1-41; quiz S42-4, 2010.

De Vogelaere, K.; Van De Winkel, N.; Aerts, M.; Haentjens, P.; Spitali, C.; Van Loo, I. \& Delvaux, G. Surgical management of gastrointestinal stromal tumours: a single centre experience during the past 17 years. Acta Chir. Belg., 114(3):167-73, 2014.

Fernández, J. A. \& Parrilla, P. Surgical treatment of an advanced GIST the age of imatinib. Cir. Esp., 86(1):3-12, 2009.

Fernández, J. A.; Sánchez-Cánovas, M. E. \& Parrilla, P. Controversies in the surgical treatment of primary gastrointestinal stromal tumours (GIST). Cir. Esp., 88(2):6980, 2010.

Hassan, I.; You, Y. N.; Shyyan, R.; Dozois, E. J.; Smyrk, T. C.; Okuno, S. H.; Schleck, C. D.; Hodge, D. O. \& Donohue, J. H. Surgically managed gastrointestinal stromal tumors: a comparative and prognostic analysis. Ann. Surg. Oncol., 15(1):52-9, 2008.

Heinrich, M. C. \& Corless, C. L. Gastric GI stromal tumors (GISTs): the role of surgery in the era of targeted therapy. J. Surg. Oncol., 90(3):195-207, 2005.

Hjermstad, B. M.; Sobin, L. H. \& Helwig, E. B. Stromal tumors of the gastrointestinal tract: myogenic or neurogenic? Am. J. Surg. Pathol., 11(5):383-6, 1987.

Kasetsermwiriya, W.; Nagai, E.; Nakata, K.; Nagayoshi, Y.; Shimizu, S. \& Tanaka, M. Surgery of upper GI gastrointestinal stromal tumors: our experience, prognostic analysis. Hepatogastroenterology, 62(137):87-92, 2015.

Kim, T. W.; Lee, H.; Kang, Y. K.; Choe, M. S.; Ryu, M. H.; Chang, H. M.; Kim, J. S.; Yook, J. H.; Kim, B. S. \& Lee, J. S. Prognostic significance of c-kit mutation in localized gastrointestinal stromal tumors. Clin. Cancer Res., 10(9):3076-81, 2004.

Koh, Y. X.; Chok, A. Y.; Zheng, H. L.; Tan, C. S.; Chow, P. K.; Wong, W. K. \& Goh, B. K. A systematic review and metaanalysis comparing laparoscopic versus open gastric resections for gastrointestinal stromal tumors of the stomach. Ann. Surg. Oncol., 20(11):3549-60, 2013. 
Liang, J. W.; Zheng, Z. C.; Zhang, J. J.; Zhang, T.; Zhao, Y.; Yang, W. \& Liu, Y. Q. Laparoscopic versus open gastric resections for gastric gastrointestinal stromal tumors: a meta-analysis. Surg. Laparosc. Endosc. Percutan. Tech., 23(4):378-87, 2013.

Lin, S. C.; Huang, M. J.; Zeng, C. Y.; Wang, T. I.; Liu, Z. L. \& Shiay, R. K. Clinical manifestations and prognostic factors in patients with gastrointestinal stromal tumors. World $J$. Gastroenterol., 9(12):2809-12, 2003.

Manrique, M. N.; Soriano, C.; Yábar, A.; Frisancho, O. \& Palacios, A. M. Gastrointestinal stromal tumors: clinicopathologic and survival evaluation in Rebagliati Hospital. Rev. Gastroenterol. Peru, 32(4):357-65, 2012.

Manterola, C. \& Astudillo, P. Checklist for reporting of descriptive observational studies. MINCIR initiative. Int. J. Morphol., 31(1):115-20, 2013.

Martín, J.; Poveda, A.; Llombart-Bosch, A.; Ramos, R.; LópezGuerrero, J. A.; García del Muro, J.; Maurel, J.; Calabuig, S.; Gutierrez, A.; González de Sande, J. L.; Martínez, J.; De Juan, A.; Laínez, N.; Losa, F.; Alija, V.; Escudero, P.; Casado, A.; García, P.; Blanco, R.; Buesa, J. M. \& Spanish Group for Sarcoma Research. Deletions affecting codons 557-558 of the cKIT gene indicate a poor prognosis in patients with completely resected gastrointestinal stromal tumors: a study by the Spanish Group for Sarcoma Research (GEIS). J. Clin. Oncol., 23(25):6190-8, 2005.

Ohtani, H.; Maeda, K.; Noda, E.; Nagahara, H.; Shibutani, M.; Ohira, M.; Muguruma, K.; Tanaka, H.; Kubo, N.; Toyokawa, T.; Sakurai, K.; Yamashita, Y.; Yamamoto, A. \& Hirakawa, K. Meta-analysis of laparoscopic and open surgery for gastric gastrointestinal stromal tumor. Anticancer Res., 33(11):503141, 2013.

Parikh, P. M. \& Gupta, S. Management of gastrointestinal stromal tumor: the imatinib era and beyond. Indian J. Cancer, 50(1):3140, 2013.

Pierie, J. P.; Choudry, U.; Muzikansky, A.; Yeap, B. Y.; Souba, W. W. \& Ott, M. J. The effect of surgery and grade on outcome of gastrointestinal stromal tumors. Arch. Surg., 136(4):383-9, 2001.

Reichardt, P.; Blay, J. Y.; Boukovinas, I.; Brodowicz, T.; Broto, J. M.; Casali, P. G.; Decatris, M.; Eriksson, M.; Gelderblom, H.; Kosmidis, P.; Le Cesne, A.; Pousa, A. L.; Schlemmer, M.; Verweij, J. \& Joensuu, H. Adjuvant therapy in primary GIST: state-of-the-art. Ann. Oncol.,23(11):2776-81, 2012.

Richter, K. K.; Schmid, C.; Thompson-Fawcett, M.; Settmacher, U. \& Altendorf-Hofmann, A. Long-term follow-up in 54 surgically treated patients with gastrointestinal stromal tumours. Langenbecks Arch. Surg., 393(6):949-55, 2008.

Rutkowski, P.; Nowecki, Z. I.; Michej, W.; Debiec-Rychter, M.; Woz'niak, A.; Limon, J.; Siedlecki, J.; Grzesiakowska, U.; Kakol, M.; Osuch, C.; Polkowski, M.; G?uszek, S.; Zurawski,
Z. \& Ruka, W. Risk criteria and prognostic factors for predicting recurrences after resection of primary gastrointestinal stromal tumor. Ann. Surg. Oncol., 14(7):201827, 2007.

Schindler, C. G.; Armbrust, T.; Gunawan, B.; Langer, C.; Füzesi, L. \& Ramadori, G. Gastrointestinal stromal tumor (GIST) -single center experience of prolonged treatment with imatinib. Z. Gastroenterol., 43(3):267-73, 2005.

Silberhumer, G. R.; Hufschmid, M.; Wrba, F.; Gyoeri, G.; Schoppmann, S.; Tribl, B.; Wenzl, E.; Prager, G.; Laengle, F. \& Zacherl, J. Surgery for gastrointestinal stromal tumors of the stomach. J. Gastrointest. Surg., 13(7):1213-9, 2009.

Schwameis, K.; Fochtmann, A.; Schwameis, M.; Asari, R.; Schur, S.; Köstler, W.; Birner, P.; Ba-Ssalamah, A.; Zacherl, J.; Wrba, F.; Brodowicz, T. \& Schoppmann, S. F. Surgical treatment of GIST--an institutional experience of a high-volume center. Int. J. Surg., 11(9):801-6, 2013.

Sorour, M. A.; Kassem, M. I.; Ghazal, Ael-H.; El-Riwini, M. T. \& Abu Nasr, A. Gastrointestinal stromal tumors (GIST) related emergencies. Int. J. Surg., 12(4):269-80, 2014.

Tielen, R.; Verhoef, C.; van Coevorden, F.; Gelderblom, H.; Sleijfer, S.; Hartgrink, H. H.; Bonenkamp, J. J.; van der Graaf, W. T. \& de Wilt, J. H. Surgical treatment of locally advanced, nonmetastatic, gastrointestinal stromal tumours after treatment with imatinib. Eur. J. Surg. Oncol., 39(2):150-5, 2013.

Wong, N. A.; Young, R.; Malcomson, R. D.; Nayar, A. G.; Jamieson, L. A.; Save, V. E.; Carey, F. A.; Brewster, D. H.; Han, C. \& AlNafussi, A. Prognostic indicators for gastrointestinal stromal tumours: a clinicopathological and immunohistochemical study of 108 resected cases of the stomach. Histopathology, 43(2):118-26, 2003.

Wu, T. J.; Lee, L. Y.; Yeh, C. N.; Wu, P. Y.; Chao, T. C.; Hwang, T. L.; Jan, Y. Y. \& Chen, M. F. Surgical treatment and prognostic analysis for gastrointestinal stromal tumors (GISTs) of the small intestine: before the era of imatinib mesylate. B. M. C. Gastroenterol., 6:29, 2006.

Zovak, M.; Boban, M.; Boban, L.; Cicek, S.; Madzar, Z.; Belev, B. $\&$ Tomas, D. Significance of surgery for prognosis of GIST in cohort from transitional healthcare settings. Int. J. Surg., 12(11):1167-71, 2014.

\section{Correspondence to:}

Dr. Carlos Manterola, MD, Ph.D.

Department of Surgery

Universidad de La Frontera

Temuco

CHILE

Received: 24-02-2016

Accepted: 25-04-2016

Email: carlos.manterola@ufrontera.cl 